\title{
STRATEGI PERPUSTAKAAN UIN SUNAN KALIJAGA YOGYAKARTA MENGHADAPI KEBIJAKAN PEMANGKASAN ANGGARAN
}

\author{
Ida Nor'aini Hadna \\ UIN Sunan Kalijaga Yogyakarta \\ hadnaaini@gmail.com
}

\begin{abstract}
Abstrak
Pada bulan Agustus 2016 pemerintah melakukan kebijakan pemangkasan anggaran guna menanggulangi kondisi perekonomian di Indonesia. Kebijakan tersebut tentu saja harus diikuti oleh semua instansi pemerintah, termasuk Perpustakaan UIN Sunan Kalijaga. Perencanaan program kegiatan yang telah diajukan sebelumnya, otomatis harus direvisi guna menyesuaikan keadaan anggaran yang ada. Dari 16 program kegiatan yang telah dianggarkan, hanya 4 program kegiatan yang dapat dilaksanakan. Sebagai lembaga penyedia informasi ilmiah yang mendukung program Tri Dharma Perguruan Tinggi, maka perpustakaan walau berada dalam keterbatasan anggaran, perlu tetap mengembangkan diri agar dapat meningkatkan layanannya kepada pemustaka. Kebijakan pemangkasan anggaran tersebut telah memicu kreativitas SDM untuk tetap dapat menjalankan dan mengembangkan instansinya dengan anggaran yang minimalis atau bahkan dengan anggaran nol rupiah ( Rp 0,00). Perpustakaan UIN Sunan Kalijaga melakukan strategi dengan inovasi kegiatan yang tanpa menggunakan anggaran dari pemerintah. Oleh karena itu, kegiatan ini disebut 'kegiatan nol rupiah".
\end{abstract}

Kata Kunci : manajemen strategi, inovasi perpustakaan, pemangkasan anggaran, kegiatan nol rupiah 


\section{A. Pendahuluan}

\section{Latar Belakang}

Pada tanggal 3 Agustus 2016 dalam Sidang Kabinet Paripurna di Kantor Presiden, Jakarta, Presiden RI Joko Widodo menyetujui pemotongan anggaran yang diusulkan oleh Menteri Keuangan, Sri Mulyani Indrawati yang melakukan pemotongan anggaran sebesar Rp 133,8 triliun dari Anggaran Pendapatan dan Belanja Negara (APBN) 2016 (Arie C. Meliala, 2016). Selanjutnya, menurut Sri Mulyani alasan melakukan revisi APBN 2016 adalah (a) setelah melihat realisasi APBN selama 2014 hingga 2015; penerimaan perpajakan mengalami tekanan yang sangat berat, harga komoditas seperti minyak dan gas, batubara, kelapa sawit, dan barang tambang lainnya mengalami penurunan sehingga otomatis penerimaan negara ikut turun cukup besar; (b) sektorsektor seperti perdagangan dan konstruksi yang mengalami tekanan dilihat dari volume aktivitas, pertumbuhan sektor-sektor itu hanya separuh dari tahun-tahun sebelumnya; (c) kondisi dunia yang mengalami pelemahan sehingga mengakibatkan perdagangan luar negeri mengalami kontraksi; statistik ekspor dan impor mengalami kontaksi sejak kuartal pertama 2015 hingga semester pertama 2016 (Arie C. Meliala, 2016). Pemangkasan anggaran yang dilakukan oleh pemerintah seperti tersebut di atas menjadi topik yang cukup hangat pada tahun 2016. Instansi pemerintah yang sudah menyusun anggaran dan kegiatan sejak setahun sebelumnya, harus merevisinya. Demikian pula yang harus dilakukan oleh Perpustakaan UIN Sunan Kalijaga. Dari 16 kegiatan yang diajukan, karena kebijakan pemangkasan anggaran dari pemerintah akhirnya hanya empat kegiatan yang dapat dilaksanakan. Walaupun demikian, kebijakan pemotongan anggaran bukan menjadi akhir dari segalanya bagi suatu instansi. Organisasi harus tetap berjalan walau dengan anggaran minimalis.

Selanjutnya, apa yang dilakukan Perpustakaan UIN Sunan Kalijaga menghadapi kebijakan pemangkasan anggaran ini? Berikut di bawah ini akan disampaikan pembahasannya. 


\section{Rumusan Masalah}

Berdasarkan latar belakang di atas, maka rumusan masalahnya adalah:

Strategi apakah yang dilakukan oleh Perpustakaan UIN Sunan Kalijaga dalam menghadapi kebijakan pemangkasan anggaran dari pemerintah?

\section{Metodologi Penelitian}

Makalah ini ditulis dengan menggunakan metode kualitatif dan deskriptif dengan teknik wawancara. Wawancara dilakukan kepada Kepala perpustakaan UIN Sunan Kalijaga Yogyakarta sebagai penentu kebijakan. Sumber data penelitian merupakan sumber data primer, yaitu sumber data yang langsung memberikan data kepada pengumpul data (Sugiyono, 2012, p. 225).

\section{Tinjauan Pustaka}

Sudah banyak penelitian yang dilakukan tentang strategi. inovasi. Penulis hanya akan menyampaikan dua sumber, yaitu pertama, penelitian yang dilakukan oleh Nurul Aidha Aminudin (Nurul Aidha Aminudin, 2018). Dalam Tesisnya tersebut Nurul meneliti tentang inovasi layanan yang dilakukan oleh Dinas Perpustakaan dan Kearsipan kota Yogyakarta. Inovasi ini dilakukan karena menurunnya jumlah peminjaman koleksi meskipun jumlah pengunjung meningkat serta adanya kritikan berulang-ulang dari pemustaka yang tidak pernah terjawab secara langsung. Oleh karena itu, dibuatlah inovasi layanan Sistem Interaktif Pemustaka (SISKA) yang berisi layanan kritik, saran, usulan buku. Hasil dari Inovasi Layanan SISKA adalah adanya peningkatan kunjungan dan peningkatan peminjaman koleksi. Kedua, makalah yang ditulis oleh Jennifer Rowley dengan tujuan utuk mengembangkan pendekatan yang lebih holistik dan strategis tentang kegiatan inovasi perpustakaan guna meningkatkan kinerja dan kemampuan inovasi. Makalah ini dimulai dengan ulasan tentang sifat inovasi dan dilanjutkan dengan membahas secara singkat tujuh aspek inovasi yang dapat bermanfaat sebagai aspek dari strategi inovasi, yaitu 
kemampuan inovasi dan budaya; portofolio inovasi; proses inovasi; kepemimpinan inovasi; tim inovatif dan kreatif; inovasi dan kolaborasi terbuka; dan keterlibatan pengguna dalam inovasi. Perencanaan dan refleksi berkelanjutan pada semua ini akan menjadi dasar yang kuat untuk pendekatan yang lebih holistik, dan dinamis untuk kegiatan inovasi dalam perpustakaan (Jennifer Rowley, 2011). Di antara kedua makalah tersebut belum ada yang meneliti tentang kebijakan manajemen startegi inovasi yang dilakukan oleh Perpustakaan UIN Sunan Kalijaga Yogyakarta.

\section{B. Pembahasan}

Pemangkasan anggaran negara seperti telah disampaikan di depan merupakan kebijakan yang tidak dapat dihindari oleh semua instansi pemerintah. Sementara itu, kegiatan organisasi harus tetap berjalan seperti sedia kala. Oleh karena itu, menghadapi situasi seperti ini diperlukan kreativitas agar aktivitas lembaga berjalan normal. Lembaga perlu melakukan manajemen strategi. Menurut John A.Pearce dan Richard B. Robinson manajemen strategis merupakan suatu rangkaian keputusan dan tindakan yang menghasilkan formulasi dan implementasi rencana untuk mencapai tujuan perusahaan (John A.Pearce II; Richard B.Robinson, Jr, 2013, p. 3). Sejalan dengan definisi tersebut, menurut Hadari Nawawi (Hadari Nawawi, 2012, p. 149) manajemen startegik adalah arus keputusan dan tindakan yang mengarah pada pengembangan suatu strategi atau strategi-strategi yang efektif untuk membantu mencapai tujuan organisasi. Dalam dunia bisnis yang dimaksud manajemen strategi adalah usaha manajerial menumbuhkembangkan kekuatan perusahaan untuk mengeksploitasi peluang bisnis yang muncul guna mencapai tujuan perusahaan yang telah ditetapkan sesuai dengan visi yang telah ditentukan (Suwarsono Muhammad, 2002, p. 6).

Pemangkasan anggaran oleh pemerintah perlu didukung berbagai pihak. Perpustakaan UIN Sunan Kalijaga sebagai instansi pemerintah tentu saja juga harus mengikuti program 
pemerintah tersebut karena sebagian anggarannya juga ikut terpangkas. Karena kebijakan ini ditetapkan pada pertengahan tahun, maka hal ini menjadi problem bagi perencanaan program kerja yang telah diajukan. Dalam menghadapi problem seperti ini, peran pimpinan sangat diperlukan untuk mengambil keputusan. Problem merupakan sebuah penyimpangan dari standard tertentu atau sesuatu tingkat dimensi tertentu yang cukup penting untuk dipecahkan (George R.Terry, 2012, p. 105). Dalam hal ini problem yang dihadapi adalah program kegiatan yang sudah biasa dilakukan tersebut memerlukan anggaran, sedangkan adanya kebijakan pemangkasan anggaran membuat kegiatan-kegiatan yang sudah diajukan tidak dapat dilakukan lagi karena tidak ada anggarannya. Oleh karena itu, diperlukan pemecahan untuk menghadapi problem tersebut. Diperlukan strategi agar kegiatan dan pengembangan perpustakaan tetap dapat berjalan dengan baik walaupun dengan anggaran yang minimalis. Jadi pada dasarnya layanan prima kepada pemustaka tetap harus dilakukan dalam situasi apa pun.

Dalam wawancara yang dilakukan dengan Kepala Perpustakaan UIN Sunan Kalijaga, Labibah Zain, beliau mengatakan bahwa lembaga harus tetap survive walau anggaran dipangkas. Oleh karena itu, pimpinan perpustakaan mengadakan inovasiinovasi kegiatan yang tidak memerlukan anggaran pemerintah.

Untuk mengetahui strategi yang dilakukan oleh Perpustakaan UIN Sunan Kalijaga dalam menghadapi kebijakan pemerintah tentang pemangkasan anggaran, maka sebelumnya perlu disampaikan gambaran singkat tentang kegiatan-kegiatan yang dilakukan oleh perpustakaan UIN Sunan Kalijaga sebelum adanya kebijakan pemangkasan anggaran dari pemerintah. Oleh karena itu, pembahasan di bawah ini akan dibagi menjadi dua sub bab, yaitu (a) program kegiatan sebelum pemotongan anggaran dan (b) program kegiatan setelah pemotongan anggaran. Uraiannya adalah sebagai berikut: 


\section{Program Kegiatan Sebelum Pemotongan Anggaran}

Sebagaimana tahun-tahun sebelumnya, Perpustakaan UIN Sunan Kalijaga selalu mengajukan anggaran untuk mendukung operasional kegiatan perpustakaan. Anggaran tersebut antara lain adalah untuk pengadaan buku tercetak, pengadaan e-book dan e-journal, langganan surat kabar dan majalah, pengadaan sarana prasarana beserta pemeliharaannya seperti komputer, printer, AC, MPS, kunci locker, locker, lampu, lift, pemberian kapur barus untuk koleksi buku, suntik anti rayap, honor piket layanan sabtu dan layanan malam, pembelian alat tulis kantor (ATK), honor mahasiswa part time, dan lain-lain. Selain itu, perpustakaan juga melaksanakan berbagai kegiatan untuk mendukung perkembangan SDM, seperti mengirim pustakawan untuk mengikuti seminar, workshop, diklat, melakukan kegiatan AMT (achievement motivation training). Perpustakaan setiap tahun juga rutin menyelenggarakan rapat kerja penyusunan rencana kegiatan dan rapat kerja evaluasi kegiatan, user education untuk mahasiswa baru, baik untuk mahasiswa S1 maupun untuk mahasiswa pasca sarjana, diskusi bulanan pustakawan, dan digitalisasi koleksi. Kegiatankegiatan lain yang sering dilakukan adalah penyelenggaraan seminar, diskusi buku, workshop, dan pameran buku, baik kegiatan tersebut dilaksanakan sendiri oleh perpustakaan maupun bekerja sama dengan pihak lain seperti kedutaan, penerbit, atau lembaga lain.

Pada pertengahan tahun 2016, ketika kebijakan pemangkasan anggaran dilakukan oleh pemerintah, maka kegiatankegiatan beranggaran yang sudah diajukan sejak tahun 2015 tentu saja harus disesuaikan dengan program kebijakan pemerintah. Dengan kata lain, kegiatan-kegiatan yang telah diajukan juga ikut terkena dampak kebijakan pemangkasan anggaran. Dari enam belas kegiatan yang telah diajukan, tinggal empat kegiatan saja yang dapat dilaksanakan. Kegiatan-kegiatan tersebut adalah seperti daftar berikut di bawah ini. 
Daftar Kegiatan Perpustakaan UIN Sunan Kalijaga dalam RKAKL tahun 2016 (sebelum pemotongan anggaran)

\begin{tabular}{|c|l|l|}
\hline No & Jenis & \multicolumn{1}{|c|}{ Kegiatan } \\
\hline 1 & BOPTN & Kegiatan TOT User Education \\
\hline 2 & & User Education Bagi Mahasiswa Baru UPT Perpustakaan \\
\hline 3 & & Rapat Koordinasi evaluasi Kerja Perpustakaan (rdk) \\
\hline 4 & & Rapat koordinasi rencana kerja perpustakaan (rdk) \\
\hline 5 & & Workshop Literasi Informasi \\
\hline 6 & & Workshop Review RIP \\
\hline 7 & & FGD RIP Perpustakaan \\
\hline 8 & & Finalisasi Penyusunan RIP Perpustakaan (rdk) \\
\hline 9 & & Workshop Sosialisasi RIP ( 1 hr) \\
\hline & & \\
\hline 1 & BLU & User education untuk mahasiswa Pasca Sarjana \\
\hline 2 & & Diskusi Bulanan pustakawan \\
\hline 3 & & Penyusunan buku \\
\hline 4 & & AMT \\
\hline 5 & & Digitalisasi karya ilmiah \\
\hline 6 & & Seminar nasional RDA \\
\hline 7 & & Lokakarya kajian naskah Islam Jawa \\
\hline & & \\
\hline
\end{tabular}

\section{Daftar Kegiatan Perpustakaan UIN Sunan Kalijaga dalam RKAKL tahun} 2016 (yang dapat dilaksanakan setelah pemotongan anggaran)

\begin{tabular}{|c|c|l|}
\hline No & Jenis & \multicolumn{1}{|c|}{ Kegiatan } \\
\hline 1 & BOPTN & Kegiatan TOT User Education \\
\hline 2 & & User Education Bagi Mahasiswa Baru UPT Perpustakaan \\
\hline 3 & & Rapat Koordinasi evaluasi Kerja Perpustakaan (rdk) \\
\hline & & \\
\hline 1 & BLU & User education untuk mahasiswa Pasca Sarjana \\
\hline
\end{tabular}

Berdasarkan data tersebut dapat diketahui bahwa dari enam belas kegiatan yang sudah diajukan, hanya tinggal empat kegiatan beranggaran yang dapat dilaksanakan, yaitu TOT User Education, User Education bagi Mahasiswa Baru, Rapat Koordinasi Evaluasi Kerja Perpustakaan, dan User Education untuk mahasiswa Pasca Sarjana. 


\section{Program Kegiatan Sesudah Pemotongan Anggaran}

Strategi yang dilakukan oleh pimpinan Perpustakaan UIN Sunan Kalijaga guna menyikapi kebijakan pemotongan anggaran tersebut adalah melakukan inovasi dengan cara melakukan kerja sama dengan berbagai pihak, seperti pimpinan-pimpinan universitas antara lain rektor, wakil rektor, para dekan, para alumni, rekanan, dan lain-lain. Melalui kerja sama dengan berbagai pihak ini, maka Perpustakaan UIN Sunan Kalijaga tetap dapat mengadakan berbagai kegiatan guna mengembangkan perpustakaan walau dengan anggaran nol rupiah (anggaran pemerintah). Anggarananggaran yang diperlukan untuk melakukan kegiatan diperoleh melalui kerja sama dengan berbagai pihak seperti tersebut di atas. Oleh karena itu, kegiatan-kegiatan di Perpustakaan UIN Sunan Kalijaga yang tidak menggunakan anggaran pemerintah tersebut dikenal dengan istilah "kegiatan nol rupiah".

Menjawab pertanyaan penulis tentang tujuan diadakannya "kegiatan nol rupiah", Labibah menjawab bahwa tujuan diadakannya kegiatan nol rupiah selain menjaga keberlangsungan programprogram kegiatan di perpustakaan (survive), juga untuk melatih mental dan kreativitas staf agar jiwa enterpreuneurshipnya muncul. Menurut Taufiq Amir, perusahaan yang memilih inovasi sebagai bagian dari pilihan startegi mereka akan membuat organisasi dapat bertahan, maju, dan berkembang (M. Taufiq Amir, 2012, p. 230). Deiss menggambarkan bahwa inovasi sebagai sesuatu yang mengubah cara kita, dapat melakukan hal yang ingin dilakukan dan itu menambah nilai bagi kehidupan kita (Jennifer Rowley, 2011, p. 253). Sejalan dengan Labibah yang mengaitkan kegiatan nol rupiah dengan kreativitas staf, Barringer dan Irlandia juga mengaitkan inovasi dengan kreativitas dan perilaku wirausaha yang dirancang untuk berkontribusi nilai ekonomi, sosial atau budaya (Jennifer Rowley, 2011, p. 253).

Selanjutnya, kegiatan-kegiatan non-budgeter yang telah dilakukan adalah oleh Perpustakaan UIN Sunan Kalijaga antara lain adalah: 
a. Perayaan Memperingati Bulan Gemar Membaca dan Hari Kunjung Perpustakaan

b. Perayaan Memperingati Hari Batik Nasional

c. Perayaan Memperingati Hari Santri Nasional

d. Belajar bareng pustakawan

e. Literasi Informasi

f. Seleksi Mahasiswa Part Time

g. Menerima Kunjungan Tamu (termasuk mahasiswa magang)

Uraian masing-masing kegiatan adalah sebagai berikut:

\section{Memperingati Bulan Gemar Membaca dan Hari}

\section{Kunjung Perpustakaan}

Bulan September dalam kalender nasional memiliki dua momen penting karena bulan kesembilan itu dijadikan sebagai Bulan Gemar Membaca dan tanggal 14 September diperingati sebagai Hari Kunjung Perpustakaan. Kedua peristiwa yang telah diresmikan oleh Presiden Soeharto di Banjarmasin pada tanggal 14 September 1995 tersebut dibuat untuk membangun kesadaran akan pentingnya peranan perpustakaan dan betapa membaca memberikan efek yang baik bagi bangsa (Pelangi Karismakristi, 2016). Untuk memperingati peristiwa tersebut, perpustakaan di berbagai penjuru tanah air ikut merayakannya, termasuk di dalamnya adalah Perpustakaan UIN Sunan Kalijaga.

Peringatan Hari Kunjung Perpustakaan yang jatuh perayaan diadakan bertepatan dengan pelaksanaan kegiatan pendidikan pemakai (user education) bagi mahasiswa baru. Suasana pengenalan perpustakaan kepada mahasiswa baru yang biasanya membuat perpustakaan menjadi tambah meriah daripada hari-hari biasanya, maka pada hari tersebut suasana perpustakaan menjadi lebih meriah lagi karena adanya peringatan Hari Kunjung Perpustakaan yang puncaknya dilaksanakan pada tanggal 14 September. Suasana 
hari itu terasa berbeda dengan hari-hari biasanya karena seluruh pegawai dan mahasiswa part time mengenakan kostum busana tradisional.

Suasana Perpustakaan UIN Sunan Kalijaga yang tingkat kunjungan per harinya rata-rata mencapai 1.500 orang, pada peringatan tersebut terasa bertambah ramai karena diadakan pameran koleksi kuno, seperti jurnal-jurnal terbitan UIN Sunan Kalijaga pada masa-masa awal, jurnal Al-Jamiah, jurnal Asy-Syir'ah, majalah-majalah kuno, bukubuku terbitan lama, Al-Quran kuno, buku terkecil, buku terberat, buku terlama, dan lain-lain.

Dalam pameran tersebut juga ditunjukkan tentang vandalisme koleksi, yaitu perusakan/penyobekan koleksi oleh pengunjung yang tidak bertanggung jawab. Hal ini menunjukkan kepada pemustaka bahwa tidakan tersebut tidak terpuji.

Yang tak kalah menariknya dalam kegiatan tersebut adalah "Pojok curhat mamake". Mahasiswa silih berganti berkonsultasi tentang karya ilmiah yang sedang ditulisnya maupun tentang cara mengakses e-resources yang dimiliki oleh perpustakaan. Yang berperan sebagai mamake adalah ibu Wahyani, pustakawan dan Kour Layanan Referensi.

Pada hari itu, perpustakaan juga melakukan remisi denda bagi para pemustaka, yaitu yang terkena denda Rp 2.000 ke bawah tidak dikenakan denda pada hari itu. Tentu saja kesempatan tersebut banyak dimanfaatkan oleh para mahasiswa.

Kegiatan terheboh yang paling banyak diminati pengunjung adalah lomba shelfi di perpustakaan. Lomba yang memperebutkan hadiah tertinggi dari Rektor UIN Sunan Kalijaga ini diikuti baik oleh dosen, mahasiswa, maupun masyarakat. Berbondong-bondong para mahasiswa, dosen, bahkan Rektor ikut bershelfi ria di depan booth yang telah disediakan di perpustakaan. 
Ada berbagai hadiah yang diberikan kepada para pemustaka dalam kegiatan untuk memperingati kunjung perpustakaan tersebut. Selain lomba selfie, juga diberikan hadiah kepada pengunjung dari dosen yang paling sering mengunjungi/mengakses perpustakaan. Yang perlu dicatat, hadiah yang diberikan kepada para pemenang semuanya merupakan kontribusi dari para sponsor, yaitu rektor, dekan, dan wakil dekan dari berbagai fakultas. Kerja sama yang dilakukan oleh perpustakaan dengan para stakeholder dan unit-unit terkait ini sangat penting dilakukan untuk mempromosikan perpustakaan di lingkungan internal sivitas akademika.

Sungguh meriah suasana pada hari kunjung perpustakaan itu. Menurut Kepala Perpustakaan, Labibah Zain, kegiatan hari kunjung perpustakaan yang dikemas dengan ringan dan santai ini dilaksanakan dengan harapan untuk lebih mensosialisasikan perpustakaan serta meningkatkan kunjungan sivitas akademika ke perpustakaan baik secara fisik maupun maya guna mengakses sumbersumber informasi yang tersedia.

\section{Memperingati Hari Batik Nasional}

Dalam rangka memperingati Hari Batik Nasional yang jatuh pada tanggal 2 Oktober, Perpustakaan UIN Sunan Kalijaga mengadakan pameran lukisan batik di lobi perpustakaan pada tanggal 3 Oktober 2016. Lukisan batik yang dipamerkan adalah hasil karya alumni, yaitu Ali D. Musyrifa dan Kajee Habib. Pameran ini sekaligus juga untuk menyambut Tahun Baru Hijriyah 1438 H dan Hari Kesaktian Pancasila. Pameran ini sangat menarik bagi para pengunjung karena memberikan suasana yang berbeda di perpustakaan. Kostum yang dikenakan oleh seluruh pegawai dan mahasiswa part time pada hari itu adalah batik. 
Sehari sebelumnya, lukisan-lukisan batik yang dipamerkan tersebut juga telah mewakili Perpustakaan UIN Sunan Kalijaga untuk mengikuti pameran di Universitas Kristen Duta Wacana (UKDW) dalam rangka memperingati hari batik dan launching buku "Batik Anti Terorisme" karya Aniek Handayani. Salah satu lukisan batik hasil karya Ali D.Musyrifa bertema batik puisi, salah satunya menggambarkan keperkasaan burung garuda yang berjuang melawan serangan dari berbagai penjuru. Hal ini dimaknai sebagai Indonesia yang berjuang melawan serangan berbagai ideologi.

\section{Memperingati Hari Santri Nasional}

Hari Santri Nasional yang telah dicanangkan oleh pemerintah setiap tanggal 22 Oktober, dirayakan oleh Perpustakaan UIN Sunan Kalijaga di lobi perpustakaan dengan mengadakan pameran kitab kuning, pembacaan sholawat dan hadroh oleh teater Eska, serta mengaji sorogan ala pondok yang disampaikan oleh Dr. Zamzam Affandi. Kegiatan yang dirayakan pada tanggal 28 Oktober 2016 ini sekaligus juga dirayakan untuk memperingati Hari Sumpah Pemuda.

Pada peringatan tersebut, suasana perpustakaan juga berbeda karena suasana pesantren terasa hadir di perpustakaan karena para pegawai pria dan mahasiswa part time hilir mudik melayani pemustaka dengan mengenakan kostum khas ala santri, yaitu sarung, baju koko, dan peci. Sedangkan yang putri mengenakan gamis.

\section{Belajar bareng pustakawan}

Guna menambah wawasan pustakawan terutama untuk melayani pemustaka dalam kegiatan Literasi informasi, maka setiap hari Rabu pustakawan melakukan "belajar bersamasama”, antara belajar tentang program zotero, mendeley, google scholer, penelusuran e-book dan e-journal, dll. 
Belajar bareng ini dibimbing oleh teman-teman sendiri yang sudah lebih berkompeten, misalnya untuk program zotero dan mendeley dibimbing oleh Fathul, penelusuran e-book \& e-journal dibimbing oleh bu Wahyani. Melalui belajar bareng ini diharapkan pengetahuan dan keterampilan pustakawan akan selalu terasah dan bertambah.

\section{Literasi Informasi}

Untuk mensosialisasikan koleksi e-journal dan e-book kita, maka pustakawan membuka kelas Literasi Informasi yang dilakukan setiap hari Selasa, pukul 09.00-11.00 di ruang Serbaguna Perpustakaan UIN Sunan Kalijaga. Dalam kegiatan ini dilakukan bimbingan penelusuran yang dipimpin pustakawan referensi. Peserta yang ingin mengikuti, baik dosen maupun mahasiswa, dapat mendaftar terlebih dulu di bagian Informasi Perpustakaan UIN Sunan Kalijaga atau datang langsung ke ruang serbaguna.

Pada awal kegiatan masih difokuskan pada bimbingan penelusuran e-resources. Pada masa mendatang materi akan ditingkatkan lagi seperti manajemen referensi menggunakan zotero/mendeley, google scholer, plagiarism cheker.

\section{Seleksi Mahasiswa Part Time}

Keberadaan mahasiswa Part time sangat membantu layanan perpustakaan. Buku-buku yang ada di meja baca setelah dibaca pemustaka maupun buku yang telah dikembalikan yang sehari rata-rata bisa mencapai 4.000 (empat ribu) eksemplar, dapat seegra tertata kembali di rak karena peran mahasiswa part time. Kegiatan layanan pada jam istirahat pegawai (jam 12.00-13.00) atau pada saat kegiatan rapat-rapat yang harus dihadiri oleh seluruh pegawai, tidak menjadi masalah lagi, layanan perpustakaan tetap berjalan.

Pada tahun 2016 dan sebelumnya mahasiswa part time berjumlah 25 orang. Pengadaannya dilakukan melalui 
kegiatan seleksi mahasiswa part time yang masuk dalam kegiatan yang ada di RKAKL. Tahun anggaran 2017, mahasiswa part time perpustakaan hanya berjumlah 13 orang ( 1 orang untuk difabel corner). Untuk perekrutannya, walaupun tidak ada dalam RKAKL, tetap dilakukan melalui seleksi seperti biasa, yaitu melalui seleksi wawancara dan praktek. Bedanya, karena yang akan diambil hanya sedikit 913 orang, maka jumlah pendaftar pun dibatasi hanya 30 orang, 15 orang untuk pendaftar perempuan dan 15 orang pendaftar pria. Setelah diumumkan yang lolos seleksi, maka juga dilakukan pembekalan untuk mahasiswa part time yang baru terpilih tersebut. Tujuannya untuk mengenalkan lebih jauh tentang perpustakaan, terutama yang berhubungan dengan tugas mereka, yaitu shelving, layanan, penelusuran e-resources.

\section{Menerima Kunjungan Tamu (termasuk mahasiswa magang)}

Perpustakaan UIN Sunan Kalijaga sering mendapat kunjungan tamu dari berbagai elemen masyarakat, baik pelajar, mahasiswa, dosen, pustakawan, dan lain-lain yang ingin belajar tentang berbagai pengelolaan perpustakaan. Kunjungan tamu berasal baik dari dalam negeri maupun luar negeri, baik dosen, peneliti, pustakawan, mahasiswa, siswa SD hingga SMA.

Perpustakaan juga menerima magang baik dari mahasiswa maupun pustakawan. Mahasiswa yang magang antara lain dari Universitas Diponegoro Semarang, Universitas Airlangga Surabaya, Universitas Negeri Malang, UIN Sunan Kalijaga, Universitas Sebelas Maret Surakarta, Universitas Kristen Satya Wacana (UKSW) Salatiga, dan lain-lain. Sementara itu, pustakawan yang magang berasal dari Stain Kendari, IAIN Mataram, IAIN Jambi, Universitas Sarjanawiyata Tamansiswa, dan lain-lain. 


\section{Penutup}

\section{Kesimpulan}

Berdasarkan hasil pembahasan di atas, maka dapat disimpulkan bahwa anggaran memang sangat diperlukan untuk pengembangan perpustakaan. Namun demikian, ketika anggaran yang sudah diajukan tidak dapat terpenuhi karena adanya kebijakan pemerintah, maka pengelola perpustakaan perlu membuat manajemen strategi dengan melakukan inovasi kegiatan agar perpustakaan tetap dapat berjalan dan berkembang tanpa menggantungkan anggaran pemerintah. Banyak inovasi kegiatan yang masih dapat dilakukan tanpa memerlukan anggaran (gerakan nol rupiah), contohnya seperti kegiatan-kegiatan yang telah disampaikan di depan.

\section{Saran}

Kegiatan-kegiatan nol rupiah seperti tersebut di atas dapat menjadi kegiatan yang rutin dilakukan setiap tahun. Diharapkan kegiatan seperti ini dapat menjadi inspirasi bagi perpustakaan lain yang memiliki anggaran yang minimalis. 


\section{DAFTAR PUSTAKA}

Arie C. Meliala. (2016, Agustus). Sri Mulyani Potong Rp 133,8 Triliun APBN 2016. Pikiran Rakyat. Retrieved from http:// bit.ly/2hvemal,

George R.Terry. (2012). Asas-asas Manajemen. Bandung: PT Alumni.

Hadari Nawawi. (2012). Manajemen strategik organisasi non profit bidang pemerintahan. Yogyakarta: Gajdah Mada University Press.

Jennifer Rowley. (2011). Should your library have an innovation strategy? 17 May 2011, 32(4/5), 251-265. https://doi. org/10.1108/01435121111132266

John A.Pearce II; Richard B.Robinson, Jr. (2013). Manajemen Strategis: Formulasi, implementasi, dan pengendalian. Jakarta: Salemba.

M. Taufiq Amir. (2012). Manajemen Strategik: Konsep dan Aplikasi. Jakarta: Rajawali.

Nurul Aidha Aminudin. (2018). Inovasi Layanan Sistem Interaktif Pemustaka (SISKA) dalam Peningkatan Layanan Perpustakaan di Dinas Perpustakaan dan Kearsipan Kota Yogyakarta. (UIN Sunan Kalijaga). Retrieved from http:// digilib.uin-suka.ac.id/32005/

Pelangi Karismakristi. (2016, September 14). Hari Kunjung Perpustakaan, Upaya Dongkrak Minat Baca Masyarakat. Metrotvnews. Retrieved from http://bit.ly/2fwup7m

Sugiyono. (2012). Metode Penelitian Kuantitatif Kualitatif dan $R$ \& D. Bandung: Alfabeta.

Suwarsono Muhammad. (2002). Manajemen Strategik: Konsep dan Kasus. Yogyakarta: UPP AMP YKPN. 